\title{
MARKETING MIX LYSIS TOWARDS SALES OF DURIAN SOFT AT RIAU SPECIAL HOUSEHOLDS "YOLANDA" PEKANBARU
}

\author{
Sri Widianti \\ Fakultas Ekonomi Dan Ilmu Sosial Universitas Islam Negeri Sultan Syarif Kasim Riau Pekanbaru
}

\section{ARTICLEINFO}

Keywords:

Sales

Product

Price

Promotion and Distribution

\begin{abstract}
This research was conducted at a typical souvenir shop from Riau "Yolanda" Pekanbaru which is located in the tourist market or the market under Jalan M. Yatim Pekanbaru. The purpose of this study was to determine how much influence the marketing mix has on sales of durian lempuk and what policies are taken by the company to increase sales of durian lempuk. The sampling method used accidental sampling, which is a sampling technique based on chance, namely anyone who happens to meet the researcher and meets the requirements to be used as a sample. The sample used in this study amounted to 71 people. Data analysis in this research is quantitative analysis using multiple linear regression method and the data is analyzed using SPSS 17.00 program.The results of hypothesis testing show that the calculated $\mathrm{F}$ value is $13.105>\mathrm{F}$ table is 2.35 , then the hypothesis is accepted. Then the regression model shows that simultaneously product, price, promotion and distribution affect consumers to the sale of durian lempuk at the typical Riau souvenir outlet "Yolanda. The value of R Square is 0.443 , which means $44.3 \%$ of products, prices, promotions and distributions affect consumers towards the sale of durian lempuk at typical Riau souvenir shops, while the rest $(100 \%-44.3 \%=55.7 \%)$ is influenced by -other reasons not investigated in this study.
\end{abstract}

Copyright (c) 2021 Journal of Economics.All rights reserved. is Licensed under a Creative Commons Attribution-NonCommercial 4.0 International License (CC BY-NC 4.0)

\section{INTRODUCTION}

Indonesia has various kinds of people with different backgrounds, areas of origin, interests and desires. Indonesia also has a wealth of natural resources that can be used to fulfill these human wants and needs. With these natural resources, Indonesia has many beautiful ancestral heritages, both cultural heritage and culinary heritage[1], [2]. Every region or province in Indonesia must have a cultural heritage and its food, Riau province is no exception.

Riau Opinsi, which is known as the Malay country, has a variety of special foods or souvenirs. By utilizing existing natural resources, Riau is able to create some typical Riau souvenirs that have become icons for this province. Durian fruit which is used as a raw material for making lempuk is not difficult to obtain. With available raw materials and meet production needs, the company can process it as a typical Riau food.

Along with the development and economic progress in the field of industry and services to meet the needs of the community, each company has different problems in managing and running its business, especially in carrying out the products it produces. One of the problems faced by the company is the problem of selling and distributing production to those in need, so that the resulting product can be satisfactory.

Basically every company that produces or produces goods or services requires marketing activities or marketing strategies. because marketing strategy is a tool or fundamental that is planned to achieve company goals by developing a sustainable competitive advantage through the market entered and in the marketing program used to serve the target market.[3], [4]. It seems clear that marketing is an important and absolute part that must be done by every company in order to achieve the goals desired by the company itself. 
The success of a company can be measured by the profit earned, efficiency and effectiveness in running the company's operations, but nevertheless the elements of the marketing mix strategy still demand a level of efficiency and effectiveness and carry out a solid marketing mix strategy to be able to use the opportunities and opportunities that exist in marketing. Thus, the position or position of the company in the market can be maintained[5], [6].

The business world is dynamic which is characterized by changes from time to time and the interrelationships between one and the other. Therefore, the marketing mix strategy plays a very important role for the success of a company. Likewise, the typical Riau souvenir outlet "Ylanda" which is a distribution business for typical Riau souvenirs every year has set sales targets which must be achieved by the company. In increasing sales, the company has carried out various policies in order to stimulate consumers to buy so as to increase company sales[7]. Stimuli that have been carried out by this company include holding promotions through print media, giving price discounts and creating product packaging that can attract consumers to buy these goods. [8].

The types of products marketed at the typical Riau souvenir outlet "Yolanda" include durian lempuk, durian dodol, melinjo chips, egg rendang, fish skin chips, dry chili sauce, fish crackers, pineapple chips and many other types of souvenirs typical of Riau. marketed at this outlet. However, in this study, researchers only took one type of product that was marketed, namely durian lempuk at the typical Riau souvenir outlet "Yolanda" which was located in the tourist market or the Pekanbaru bottom market.

\section{METHOD}

\section{Research time and location}

PeThis research was carried out at a typical Riau souvenir outlet "Ylanda" Pekanbaru, which is located in the tourist market or the lower market of Pekanbaru. Meanwhile, the time of the research was from January 20 to June 4 .

\section{Data types and sources}

In carrying out this research requires complete data and information. The types of data used consist of:

a. Primary data is data collected directly from the object of research. The primary data includes price, product quality, promotion and distribution carried out by the company.

b. Secondary data, namely data that is already available at the souvenir shop "Yolanda" Pekanbaru includes the number of sales of durian lempuk, a brief history of the company, and the organizational structure.

\section{Data collection technique}

To obtain the data and information needed in the study, the authors used the following data collection methods:

a) Wainterview

That is in the form of direct interviews which are expected to be carried out well on the seller's side.

b) Questionnaire

Pewrite a list of questions which are then distributed to a number of samples in the hope of responding to the list of questions.

c) Observation

Namely direct observation to the research location, related to the object of research during the research period.

\section{Population and sample}

The population in this study are consumers who shop at Yolanda Pekanbaru souvenir outlets. While the sample which is part of the population that will be used as respondents in the study is the people who shop at Yolanda Pekanbaru outlets. The sample is part or representative of the population studied. The sample in this study is the result of interviews with shop owners that those who buy durian lempuk at this outlet are consumers, totaling approximately 250 people. Due to limited funds and time, the author took a sample from the population using the slovin formula. So, the sample used in this study was 71 people. The method used in this sampling is by using the accidental sampling method,[9], [10] .

Data analysis 
The data discusses the research results obtained from the respondents' answers, so to prove the formulated hypothesis, it is necessary to process data where the analysis used is quantitative analysis and multiple linear regression.

\section{RESULTS AND DISCUSSION}

\section{Description of Respondents Characteristics}

This section will provide an overview of the respondents in terms of age group, which can be seen in the following table:

Umur Respondent

Table 1 Respondents by Age Group

\begin{tabular}{cccc}
\hline No & Respondent's Age & \multicolumn{2}{c}{ Frequery } \\
\cline { 3 - 4 } & & Person & $\%$ \\
\hline 1 & $20-30$ & 33 & $46 \%$ \\
2 & $31-40$ & 17 & $24 \%$ \\
3 & $41-50$ & 17 & $24 \%$ \\
4 & And others & 4 & $6 \%$ \\
\hline & Jumlah & 71 & $100.00 \%$
\end{tabular}

Based on Table 1 above, it is known that based on the age group of respondents ranging from 20-30 years as many as 33 people or $46 \%$, then $31-40$ years as many as 17 people or $24 \%, 41-50$ as many as 17 people or $24 \%$, and so on. -other as many as 4 people or $6 \%$ of the 71 respondents. So it can be concluded that the average age of the respondents is 20-30 years.

\section{Respondent's Job}

BagThis section will provide an overview of the respondents in terms of occupational groups, which can be seen in the following table:

Table 2. Respondents by Occupational Group

\begin{tabular}{cccc}
\hline No & Respondent's work & \multicolumn{2}{c}{ Frequery } \\
\cline { 3 - 4 } & & Person & $\%$ \\
\hline 1 & Swasta & 21 & $30 \%$ \\
2 & Pegaoh country & 23 & $32 \%$ \\
3 & Wself-ployed & 13 & $18 \%$ \\
4 & Ihousewife & 10 & $14 \%$ \\
5 & And others & 4 & $6 \%$ \\
\hline & Jumlah & 71 & $100 \%$
\end{tabular}

Based on Table 2 above, it is known that based on the occupational group, the number of respondents with private jobs is 21 people or $30 \%$, then civil servants are 23 people or $32 \%$, entrepreneurs are 13 people or $18 \%$, housewives are 10 people or by $14 \%$ and others as many as 4 people by $6 \%$ of the 71 respondents. So it can be concluded that the average respondent's job is a civil servant.

\section{Respondent's Gender}

This section will provide an overview of the respondents in terms of gender, which can be seen in the following table:

Table 3 Respondents by Gender Group

\begin{tabular}{cccc}
\hline \multirow{2}{*}{ No } & Respondent's Gender & \multicolumn{2}{c}{ Frequery } \\
\cline { 3 - 4 } & & Person & $\%$ \\
\hline 1 & Perewoman & 39 & $55 \%$ \\
2 & Laki-boy & 32 & $45 \%$ \\
& Jumlah & 71 & $100.00 \%$ \\
\hline
\end{tabular}

Marketing Mix Lysis Towards Sales Of Durian Soft At Riau Special Households "Yolanda" Pekanbaru 
BerdaBased on Table 3 above, it is known that based on the gender group of respondents, 39 people or $55 \%$ were female, then 32 people or $45 \%$ were male, from 71 respondents. So it can be concluded that the average gender of the respondents is female.

\section{Description of Frequently Asked Questions}

In this study, there were 5 (five) variables studied. Consists of 1 (one) dependent variable and 4 (four) independent variables. These variables are product, price, promotion, and distribution as independent variables and sales as dependent variable. Through the questionnaires that have been distributed, data regarding these variables are obtained as follows:

\section{Sales Analysis}

This sales variable, in the questionnaire, is represented by four positive statements. To find out the answers of respondents can be seen in Table 4.

Table 4: Recapitulation of Respondents' Responses to Variables Sale

\begin{tabular}{|c|c|c|c|c|c|c|c|}
\hline \multirow{2}{*}{ NO } & \multirow{2}{*}{ question } & \multicolumn{5}{|c|}{ Frequency } & \multirow{2}{*}{ fridaylah } \\
\hline & & SS & $\mathrm{S}$ & RR & TS & STS & \\
\hline 1 & $\begin{array}{l}\text { Sales System on by typical } \\
\text { Riau "Yolanda ' is very good }\end{array}$ & 33 & 26 & 10 & 2 & 0 & 71 \\
\hline 2 & $\begin{array}{l}\text { Special gift shop Riau } \\
\text { "Yolanda" } \\
\text { convenience (discount) in } \\
\text { making sales }\end{array}$ & 31 & 30 & 1 & 9 & 0 & 71 \\
\hline 3 & $\begin{array}{l}\text { service provided gerai } \\
\text { Yolanda in selling durian } \\
\text { lempuk is quite good }\end{array}$ & 37 & 19 & 8 & 7 & 0 & 71 \\
\hline
\end{tabular}

selling durian soft pthere is a yolanda outlet that is quite

4 competitive with the surrounding outlets

\begin{tabular}{cccccc}
34 & 20 & 12 & 4 & 1 & 71 \\
135 & 95 & 31 & 22 & 1 & 284 \\
\hline $47.53 \%$ & $33.45 \%$ & $10.92 \%$ & $7.75 \%$ & $\begin{array}{l}0.35 \\
\%\end{array}$ & $100 \%$ \\
\hline
\end{tabular}

From the research that the author did about sales and as outlined in Table 4, it can be seen that $47.53 \%$ of respondents stated strongly agree, $33.45 \%$ of respondents who agreed, $10.92 \%$ of respondents who expressed doubt, $7.75 \%$ of respondents stated disagree, $0.35 \%$ of respondents strongly disagree. The sales system for the typical Riau souvenirs "Yolanda" is very good, the typical Riau souvenir outlet "Yolanda" provides convenience (discounts) in making sales, the services provided by the Yolanda outlet in selling durian lempuk are quite good, the sale of durian lempuk at the Yolanda outlet quite competitive with the surrounding outlets.

Product Analysis

In this product variable, in the questionnaire it is represented by four statements that have positive values. To find out the answers of respondents can be seen in Table 5.

\section{Table 5 Recapitulation of Respondents' Responses to Product Variables}




\begin{tabular}{|c|c|c|c|c|c|c|c|}
\hline \multirow{2}{*}{ No } & \multirow{2}{*}{ question } & \multicolumn{5}{|c|}{ Frequency } & \multirow{2}{*}{ fridaylah } \\
\hline & & SS & $S$ & $\mathrm{RR}$ & TS & STS & \\
\hline 1 & $\begin{array}{l}\text { Lempuk Harum Sari } \\
\text { durian at a typical Riau } \\
\text { souvenir shop " } \\
\text { yolanda' has design/ } \\
\text { better shape than other } \\
\text { brands }\end{array}$ & 19 & 37 & 13 & 2 & 0 & 71 \\
\hline 2 & $\begin{array}{l}\text { Lempufragrant durian } \\
\text { sari at yolanda outlet } \\
\text { has good quality }\end{array}$ & 16 & 40 & 11 & 4 & 0 & 71 \\
\hline 3 & $\begin{array}{l}\text { Packaging and taste } \\
\text { Harum Sari durian } \\
\text { paste at Yolanda outlets } \\
\text { according to consumer } \\
\text { tastes }\end{array}$ & 21 & 33 & 13 & 4 & 0 & 71 \\
\hline 4 & $\begin{array}{l}\text { The brand of Lempuk } \\
\text { Durian Fragrant Sari } \\
\text { at Yolanda outlets is } \\
\text { well known to } \\
\text { consumers }\end{array}$ & 24 & 19 & 21 & 6 & 1 & 71 \\
\hline & fridaylah & 80 & 129 & 58 & 16 & 1 & 284 \\
\hline & percentage (\%) & $28,17 \%$ & $45.42 \%$ & $20.42 \%$ & $5.64 \%$ & $\begin{array}{l}0.35 \\
\%\end{array}$ & $100 \%$ \\
\hline
\end{tabular}

From the research that the author did about the product and stated in Table 5, it can be seen that $28.17 \%$ of respondents stated strongly agree, $45.42 \%$ of respondents who agreed, $20.42 \%$ of respondents who expressed doubt, $5.64 \%$ of respondents who stated disagree, $0.35 \%$ of respondents who stated that they strongly disagreed with Lempuk durian at the typical Riau souvenir outlet "Yolanda" had a better design / shape than other brands, Lempuk durian Harum Sari at Yolanda outlets had good quality, packaging and The taste of durian lempuk at Yolanda outlets is in accordance with consumer tastes. The brand of fragrant durian lempuk at Yolanda outlets is well known to consumers.

\section{Price Analysis}

PaIn this price variable, in the questionnaire it is represented by four positive statements. To find out the answers of the respondents can be seen in Table 6 .

Table 6 Recapitulation of Respondents' Responses to Price Variables

\begin{tabular}{|c|c|c|c|c|c|c|c|}
\hline \multirow{2}{*}{ NO } & \multirow{2}{*}{ question } & \multicolumn{5}{|c|}{ Frequency } & \multirow{2}{*}{ fridaylah } \\
\hline & & SS & $\mathrm{S}$ & RR & TS & STS & \\
\hline 1 & $\begin{array}{l}\text { The selling price of durian } \\
\text { tender there are outlets - } \\
\text { souvenir outlets typical of } \\
\text { Riau yolanda Pekanbaru } \\
\text { affordable }\end{array}$ & 31 & 29 & 6 & 5 & 0 & 71 \\
\hline
\end{tabular}


Durian soft quality which are sold at souvenir shops, typical of Riau Yolanda, are

2 very suitable for the price offered

The price of durian lemuk

3 offered is according to consumer tastes

The price of Harum Sari durian lempuk offered at Yolanda outlets is very

4 competitive with the price of durian lempuk in other stores

$\begin{array}{llllll}27 & 33 & 7 & 3 & 1 & 71\end{array}$

$\begin{array}{llllll}30 & 29 & 12 & 0 & 0 & 71\end{array}$

$\begin{array}{llllll}40 & 18 & 8 & 5 & 0 & 71\end{array}$

\begin{tabular}{ccccccc}
\hline fridaylah & 128 & 109 & 33 & 13 & 1 & 284 \\
\hline percentage (\%) & $45.07 \%$ & $38.38 \%$ & $11.62 \%$ & $4.58 \%$ & $\begin{array}{c}0.35 \\
\text { o }\end{array}$ & $100 \%$ \\
\hline
\end{tabular}

From the research that the author did about prices and stated in Table 6, it can be seen that $45.07 \%$ of respondents stated strongly agree, $38.38 \%$ of respondents who agreed, $11.62 \%$ of respondents who expressed doubts $4.58 \%$ of respondents who stated no agree, $0.35 \%$ of respondents who stated that they strongly disagreed with the statement. The selling price of durian lempuk at typical Riau Yolanda souvenir outlets, Pekanbaru. offered, the price of durian lempuk offered according to consumer tastes, the price of durian lempuk offered at Yolanda outlets is very competitive with the price of durian lempuk in other stores.

\section{AnPromotion analysis}

PaIn this promotion variable, in the questionnaire it is represented by four statements that have positive values. To find out the answers of the respondents can be seen in Table 7.

Table 7. Recapitulation of Respondents' Responses to Promotion Variables

\begin{tabular}{|c|c|c|c|c|c|c|c|}
\hline \multirow[b]{2}{*}{ NO } & \multirow[b]{2}{*}{ question } & \multicolumn{5}{|c|}{ Frequen } & \multirow[b]{2}{*}{ fridaylah } \\
\hline & & SS & $S$ & RR & TS & STS & \\
\hline 1 & $\begin{array}{l}\text { distribution of brochures } \\
\text { by yolanda outlets } \\
\text { pretty good }\end{array}$ & 23 & 26 & 14 & 8 & 0 & 71 \\
\hline 2 & $\begin{array}{l}\text { Ikand done The era of } \\
\text { typical Riau souvenirs, } \\
\text { Yolanda Pekanbaru, is } \\
\text { very intensive }\end{array}$ & 22 & 30 & 10 & 8 & 1 & 71 \\
\hline 3 & $\begin{array}{l}\text { Ikand soft durian outlet } \\
\text { yolanda through print } \\
\text { media is very interesting }\end{array}$ & 22 & 28 & 9 & 9 & 3 & 71 \\
\hline 4 & $\begin{array}{l}\text { you do it buy lempuk } \\
\text { durian at yolanda outlets } \\
\text { based on suggestions from } \\
\text { your friends }\end{array}$ & 24 & 31 & 8 & 8 & 0 & 71 \\
\hline & fridaylah & 91 & 115 & 41 & 33 & 4 & 284 \\
\hline
\end{tabular}




$\begin{array}{lllllll}\text { Ppercentage (\%) } & 32.04 \% & 40.49 \% & 14.44 \% & 11.62 \% & \begin{array}{l}1.41 \\ \%\end{array} & 100 \%\end{array}$

From the research that the author did about promotion and stated in Table V.9, it can be seen that $32.04 \%$ of respondents stated strongly agree, $40.49 \%$ of respondents who agreed, $14.44 \%$ of respondents who expressed doubt, $11.62 \%$ of respondents who stated that they did not agree and $1.41 \%$ of respondents who stated strongly disagreed with the statement The distribution of brochures by Yolanda outlets was quite good, advertisements carried out by typical souvenirs outlets of Riau Yolanda Pekanbaru were very intense, advertisements for lempuk durians at Yolanda outlets through print media were very interesting, you made a purchase of durian lempuk at Yolanda outlets based on suggestions from your friends.

\section{Distribution analysis}

PaIn this distribution variable, the questionnaire is represented by four statements that have positive values. To find out the answers of the respondents can be seen in Table 8

Table 8 Recapitulation of Respondents' Responses to Variables Distribution

\begin{tabular}{|c|c|c|c|c|c|c|c|}
\hline \multirow{2}{*}{ NO } & \multirow{2}{*}{ question } & \multicolumn{5}{|c|}{ Frequency } & \multirow{2}{*}{ fridaylah } \\
\hline & & SS & S & RR & TS & STS & \\
\hline 1 & $\begin{array}{l}\text { Productk soft durian } \\
\text { youngh found in shops in } \\
\text { the city of Pekanbaru }\end{array}$ & 27 & 35 & 8 & 1 & 0 & 71 \\
\hline 2 & $\begin{array}{l}\text { Rak- rack bcharcoal } \\
\text { according to the type of } \\
\text { product and easily } \\
\text { accessible by consumers }\end{array}$ & 38 & 24 & 5 & 4 & 0 & 71 \\
\hline 3 & $\begin{array}{l}\text { Availability of lemuk } \\
\text { durlan is always there at } \\
\text { the typical souvenir shop of } \\
\text { Riau Yolanda }\end{array}$ & 21 & 28 & 18 & 4 & 0 & 71 \\
\hline 4 & $\begin{array}{l}\text { Locationi souvenir shop } \\
\text { khas Riau yolanda } \\
\text { Pekanbaru is easy to reach } \\
\text { by public transportation }\end{array}$ & 26 & 28 & 7 & 10 & 0 & 71 \\
\hline & fridaylah & 112 & 115 & 38 & 19 & 0 & 284 \\
\hline & percentage (\%) & $39.44 \%$ & $40.49 \%$ & $13.38 \%$ & $6.69 \%$ & $0 \%$ & $100 \%$ \\
\hline
\end{tabular}

From the research that the author did about the distribution and stated in Table V.10, it can be seen that $39.44 \%$ of respondents stated strongly agree, $40.49 \%$ of respondents who agreed, $13.38 \%$ of respondents who expressed doubt, and $6.69 \%$ respondents who disagreed, $0 \%$ of respondents who stated strongly disagreed with the statement. Durian lempuk products are easy to find in shops in the city of Pekanbaru. Riau Yolanda souvenir outlets, The location of the Riau Yolanda souvenir outlets in Pekanbaru is easy to reach by public transportation.

Multiple Linear Regression Analysis

This study uses multiple linear regression, carried out using the enter method, where all variables are entered to find the effect of the independent variable on the dependent variable through regressing sales as the dependent variable and product, price, promotion and distribution as independent variables. The results of the hypothesis are as listed in Table 9 below.

\section{Table 9 Regression Results}

\section{Coefficientsa}




\begin{tabular}{|c|c|c|c|c|c|c|c|c|c|c|}
\hline \multirow[t]{2}{*}{ Model } & \multicolumn{2}{|c|}{$\begin{array}{l}\text { Unstandardize } \\
\text { d Coefficients }\end{array}$} & \multicolumn{2}{|l|}{ Standardized } & \multirow[b]{2}{*}{ Sig. } & \multicolumn{3}{|c|}{ Correlations } & \multicolumn{2}{|c|}{ Collinearity } \\
\hline & B & $\begin{array}{l}\text { Std. } \\
\text { Error }\end{array}$ & Beta & $\mathrm{t}$ & & $\begin{array}{l}\text { Zero- } \\
\text { order }\end{array}$ & Partial & Part & $\begin{array}{l}\text { Toler } \\
\text { ance }\end{array}$ & VIF \\
\hline 1 (Constant) & 5.855 & 2.384 & & 2.456 & .017 & & & & & \\
\hline $\mathrm{x} 1$ & .356 & 119 & 335 & 2.985 & 004 & .551 & .345 & .274 & .670 & 1.494 \\
\hline $\mathrm{x} 2$ & .112 & .160 & 090 & .697 & 488 & 478 & .085 & .064 & 510 & 1.963 \\
\hline x3 & 444 & .150 & 470 & 2.963 & 004 & .596 & .343 & 272 & 336 & 2.975 \\
\hline $\mathrm{x} 4$ & 186 & 169 & 155 & 1.100 & .275 & .418 & 134 & .101 & 423 & 2.364 \\
\hline
\end{tabular}

Table 10 Regression Coefficient of Effect of Independent Variables on Sale

\begin{tabular}{ccccc}
\hline Variable & $\begin{array}{c}\text { Kefficient } \\
\text { Regressi }\end{array}$ & Standar Error & T count & Sig \\
\hline produk & 0.356 & 0.119 & 2,985 & 0.004 \\
Price & 0.112 & 0.160 & 0.697 & 0.488 \\
promosi & 0.444 & 0.150 & 2,963 & 0.004 \\
Distribution & -0.186 & 0.169 & -1.100 & 0.275 \\
Constanta (a) & 5.855 & 2,384 & 2.456 & 0.017
\end{tabular}

R square : 0.443

F Ratio: 13.105

Sig : 000

PerThe regression equation from the statistical calculation results is obtained as follows:

$\mathrm{Y}=\mathrm{a}+\mathrm{b} 1 \mathrm{X} 1+\mathrm{b} 2 \mathrm{X} 2+\mathrm{b} 3 \mathrm{X} 3+\mathrm{b} 4 \mathrm{X} 4+\mathrm{e}$

$\mathrm{Y}=5.855+0.356+0.112+0.444-0.186+\mathrm{e}$

1. The constant of 5.855 means that if the product, price, promotion, distribution value is 0 (zero), then the sales value is 5.855 .

2. The regression coefficient of 0.356 states that if the product increases by 1 unit, then sales will also increase by 0.103 .

3. The regression coefficient of 0.112 states that if the price increases by 1 unit, then sales will also increase by 0.112 .

4. The regression coefficient of 0.444 states that if the promotion has increased by 1 unit, then sales will also increase by 0.444 .

5. The regression coefficient -0.186 states that the distribution has a negative effect on sales, which means that if the distribution increases by 1 unit, then sales will decrease by 0.1

\section{Discussion of Analysis Results}

Berdasuggest the regression coefficient of the independent variable partially to the dependent variable above is obtained as follows:

1. Product quality variable (X1) shows $t$ count of 2,985 $>\mathrm{t}$ table 2.00 , it can be concluded that product quality variable partially has a positive effect on sales

2. The price variable $(\mathrm{X} 2)$ shows $t$ count of $0.697<t$ table 2.00 , it can be concluded that the price variable partially does not have a positive effect on sales,

3. Promotion variable (X3) shows $t$ count of $2,963>t$ table 2.00 , it can be concluded that the promotion variable partially has a positive effect on sales,

4. The distribution variable (X4) shows $t$ count of $-1.100<t$ table 2.00 , it can be concluded that the distribution variable partially does not have a positive effect on sales.

From the results of the regression coefficient test for each of the independent variables above, it can be concluded that of the four independent variables, only product quality and promotion have a significant effect on sales of durian lempuk at the typical souvenir shop of Riau "Yolanda" Pekanbaru. 


\section{CONCLUSION}

From the results of the partial regression test, it is known that the product variable (X1) and the promotion variable (X3) have a significant influence on sales of durian lempuk with each regression, namely, Product (X1) $t$ count $>t$ table2,985 $>2,000$ and promotion (X3) $t$ arithmetic $>t$ table 2,963 > 2,000 then Ha is accepted and Ho is rejected. Meanwhile, the price variable (X2) and distribution (X4) did not have a significant effect on the sale of durian lempuk at the typical souvenir shop of Riau "Yolanda" Pekanbaru. The calculated F value is $13.105>\mathrm{F}$ table is 2.35, then the hypothesis is accepted. Then the regression model shows that simultaneously product, price, promotion and distribution affect consumers to the sale of durian lempuk at the typical Riau souvenir outlet "Yolanda. From the results of the coefficient of determination, it is known that the value of R Square is 0 ,

[1] R. Roostika, "Analisis Pengaruh Bauran Pemasaran Produk Cindera Mata terhadap Kepuasan Wisatawan Domestik di Yogyakarta," J. Manaj. dan Akunt., vol. 1, no. 3, 2012.

[2] F. Komalasari, "Pengaruh Bauran Pemasaran Terhadap keputusan Pembelian Produk Handphone Nokia Eseries," J. Manaj., no. 100, 2012.

[3] R. Yuliana, "Analisis Strategi Pemasaran Pada Produk Sepeda Motor Matik Berupa Segmentasi, Targeting, Dan Positioning Serta Pengaruhnya Terhadap Keputusan Pembelian Konsumen Di Semarang," J. STIE Semarang, vol. 5, no. 2, 2013.

[4] Y. Elsandra and A. A. Yulianto, "Strategi Pemasaran untuk Meningkatkan Usaha Kecil, Menengah berbasis Industri Kreatif melalui ICT," J. Kaji. Manaj. Bisnis, vol. 2, no. 1, 2013.

[5] I. U. Ningrum, A. Malik, and E. Kernalis, "ANALISIS STRATEGI BAURAN PEMASARAN DAN PENGARUHNYA TERHADAP VOLUME PENJUALAN AGROINDUSTRI KERUPUK KULIT (JANGEK) DI KOTA JAMBI," J. Ilm. Sosio-Ekonomika Bisnis, vol. 15, no. 1, 2012, doi: 10.22437/jiseb.v15i1.2746.

[6] F. Andika, "Analisa Strategi Marketing Gumati Cafe Dalam Meningkatkan Konsumen Menurut Perspektif Islam," J. Ekon. Islam Al-Infaq, vol. 3, no. 1, 2012.

[7] Z. A. Umar, "Strategi Bauran Pemasaran Dalam Meningkatkan Volume Penjualan Ikan Tuna Olahan Pada PT. Betel Citra Seyan Gorontalo," J. Inov., vol. 9, no. 1, 2012.

[8] D. Yudhiartika and J. O. Haryanto, "Personal Selling, Display, Promosi Penjualan Terhadap Kesadaran Merek Dan Intensi Membeli," J. Bul. Stud. Ekon., vol. 17, no. 2, 2012.

[9] T. TOTON and A. Sukma, "Analisis Faktor-Faktor Yang Mempengaruhi Loyalitas Pelanggan Produk Sim Card Flexi Trendy Pada PT. Telkom Di Kota Bandar Lampung," J. Manaj. dan Bisnis Univ. Bandar Lampung, vol. 3, no. 1, 2012.

[10] S. Sudomo, "Analisis Faktor-Faktor Yang Mempengaruhi Keputusan Pembelian Mobil Toyota Avanza Di Propinsi Daerah Istimewa Yogyakarta," Jbma, vol. I, no. 1, 2012. 